\title{
Exploring symbolic violence in the everyday: misrecognition, condescension, consent and complicity
}

\begin{abstract}
In this article, we draw on Pierre Bourdieu's concepts of 'misrecognition', 'condescension' and 'consent and complicity' to demonstrate how domination and violence are reproduced in everyday interactions, social practices, institutional processes and dispositions. Importantly, this constitutes symbolic violence, which removes the victim's agency and voice. Indeed, we argue that as symbolic violence is impervious, insidious and invisible it also simultaneously legitimises and sustains other forms of violence as well. Understanding symbolic violence together with traditional discourses of violence is important because it provides a richer insight into the 'workings' of violence, provides new ways of conceptualising violence across a number of social fields and new strategies for intervention. Symbolic violence is a valuable tool for understanding contentious debates on the disclosure of violence, women leaving or staying in abusive relationships or returning to their abusers. Whilst we focus only on violence against women, we recognise that the gendered nature of violence produces its own sets of vulnerabilities against men and marginalised groups, such as LGBT. The paper draws on empirical research conducted in Sweden in 2003 by the second-author. Sweden is an interesting case study because despite its progressive gender equality policies, there has been no marked decrease in the violence towards women by men.
\end{abstract}

Keywords symbolic violence, consent, complicity, misrecognition, condescension, symbolic power, Bourdieu

\section{Introduction}

The social dynamics of everyday practices are often governed and shaped in many ways by gendered inequalities and micro contexts of power, which enable various forms of normative violence to continue with impunity. Therefore, it is important to explore how 'everyday violence', a term originally coined by Nancy Scheper-Hughes (1992; 1996) to explain social indifference towards shocking levels of suffering caused by institutional processes and 
discourses, enables various forms of violence against women to become accepted, normalised and reproduced with impunity. Similarly, Philippe Bourgois (2004; also see Klienman, 2000) examines how categories of violence - structural, symbolic, everyday and intimate - overlap, which provides a more compelling insight to the underlying causes and types of violence that exist in our everyday lives. We argue that symbolic violence is a useful conceptual and theoretical bridge to understand the embeddedness of subordination, domination and exploitation that many women experience in their everyday lives. Symbolic violence is produced, reproduced and deemed legitimate through 'schemes' that are 'immanent in everyone's habitus' (Bourdieu, 2001a: 33). Indeed, schemes, which are 'shaped by similar conditions, and therefore objectively harmonised, function as matrices of the perceptions, thoughts and actions of all members of the society', are inscribed onto bodies in the form of 'dispositions', and they can ultimately survive long after the disappearance of the social conditions of production (Bourdieu, 2001a: 33). Thus dispositions (habitus) are inseparable from the relations and structures of power that produce them. The dominated view the relations of domination from the perspective of the dominant thus making them appear as 'natural' (Bourdieu, 2001a: 35; also see Holmes, 2013).

In this paper we use the case of Sweden, a country which together with other Nordic countries is ranked high in international comparisons for its progressive and effective gender-equality policies, especially targeted for reducing gender-based violence (SIDA, 2010; Towns, 2002). As a result of such policy initiatives, Swedish criminal justice authorities are more likely to conceptualize violence against women as a crime. For instance, the Swedish Women's Peace Reform in 1998 led to a new penal code legislation on 'gross violation of a woman's integrity' 
which deals with repeated, punishable acts directed by men against women with whom they have a close relation (Niemi and Öhman, 2010). Furthermore, policy initiatives have been supported with generous public funding with the aim to implement a zero tolerance approach towards gender-based violence (Prop. 2005/06:155, cited in Burman and Öhman, 2014). Despite these efforts, a number of studies have highlighted that there has been no significant decrease in men's violence towards women in Sweden (Burman and Öhman, 2010; Lundgren, Heimer, Westerstrand \& Kalliokoski, 2001; Swahnberg, 2003; Author, 2007).

Questions remain about how such policies are translated into practice (Öhman and Emmelin, 2014; Steen, 2003). For example, Burman (2010:179) argues that the Swedish criminal legal discourse is 'masculinist' and contravenes the objective of gender-equality, particularly in using rigid discourses of the 'innocent victim' who is constructed as defenseless or the 'less innocent victim' who in contrast is constructed as provocative. She suggests that women's agency and resistance can be seen as contributing to 'victim precipitation' and consequently women 'risk having to deny their agency to be offered full criminal legal protection against violence in intimate relationships' (2010:182). Furthermore, whilst we recognize the legal advancements since the 1990s, we would argue that this has not only undermined the specificity and particularity of women's experiences but also led to more immediate focus on direct physical violence, thus ignoring the complexity of the everyday workings of violence which disempower women and erode the values of gender equality.

\section{Feminist Frameworks of Violence}


Feminist research has provided important insights into theorizing and understanding interpersonal violence. First, feminist interventions have highlighted not only the invisible and often insidious workings of male power and control within public and private spaces (Dobash $\&$ Dobash, 1997; Kelly 1996a; Kelly, Burton and Reagan, 1996b; Maynard, 1993; Radford \& Russell, 1992), but also the endemic and routine nature of such violence (Stanko, 1990, 2003, 2006). Thus, it is not necessarily the tangible act of violence, which imposes a form of social control over women, rather the 'internalization through continual socialisation' of the possibility of violence (Smart \& Smart, 1978:100). Second, feminist research has broadened definitions of violence to incorporate a range of behaviours, including emotional and psychological, as well as physical abuse, thus shifting the focus away from the 'battered woman' to look at supposedly 'lesser' physical forms of abuse that impact on women and children psychologically, and which, if not checked, can potentially lead to extreme incidents (hooks, 1997:282; also see Lamb, 1996, 1999; Loseke, 1999). For example, hooks (1997) argues that an over focus on extreme forms of physical violence leads to an acceptance of everyday physical abuse, such as occasional hitting (e.g. 'smacking'). Third, feminist writings have explored the intersecting oppressions of race, class and gender to draw attention to the ways in which the specificity of black and minority ethnic women's experiences has been mis-represented, overlooked or silenced (Gill, 2004; Crenshaw, 1991). Fourth, some accounts question the fixed identities of victim/survivor in narratives of everyday violence since the 'either/or' distinctions fail to capture the complexity of processes of victimisation (Alcoff and Gray, 1993; Naples, 2003). For example, to equate a survivor-identity with the ability to speak out might disguise the procedural nature of change and the agential potential of an (inner) silent space to develop modes of resistance (AUTHOR, 2014). Fifth, the process of 'exposure' has involved the explicit naming of violence and abuse by men 
to ensure that women's experiences of violation is not left literally unspeakable (see Kelly, 1996a). Thus, a feminist approach is characterized by a combination of consciousness-raising, intervention programmes and activism (Williamson and Abrahams, 2014).

\section{Conceptualisation of Violence in Sweden}

Theoretically, feminist research on VAW in Sweden has by and large been framed by the work of Eva Lundgren (1991), Margareta Hydén (1995), and Viveca Enander \& Carin Holmberg (2008). Lundgren's (1991) analysis of the 'normalisation process' was an important milestone in Swedish research on VAW and still remains influential today. It draws on a structural perspective on VAW and recognizes the importance of understanding violence as a 'continuum', rather than focussing on any particular form of violence (see also Kelly, 1988). However, Hydén (1995) argues that Lundgren's model potentially ascribes violated women with a passive victim identity who accept violence; while, in contrast Hydén suggests that battered women do put up resistance which enables them, for example, to leave violent relationships. Using Lundgren and Hyden as a frame of reference, Enander \& Holmberg (2008) address 'battered' women's leaving processes by describing three overlapping processes of action, emotion and cognition, and introduce the concept of a 'traumatic bond' to illustrate the bond of intertwined emotions between the violated and the violator. The entwinement of strong emotions, such as love, hate, fear, guilt and hope, which often are regarded as being in opposition to each other, work together to create strong emotional ties that bind the violated woman to her violator. Moreover, Enander and Holmberg discuss battered women's acts of resistance, and conclude that while battered women do put up resistance, these acts can, paradoxically, function as obstacles to leaving the violent partner. Thus, 'adaptation and resistance are not opposing strategies, but that resistance is 
in fact a kind of adaptation' (Enander and Holmberg, 2008:211). Furthermore, even if the women were to leave, it does not necessarily mean an end to violence in their lives. Ekbrand (2006) observes that violence can continue after the separation.

There is a burgeoning though controversial body of literature that suggests a more multifaceted and refined discussion on gender and violence by introducing the idea of 'gender symmetry', which illustrates how women's violence towards men is comparable to men's violence towards women in intimate relationships. So, men are equally vulnerable to violence in intimate relations (see Enander, 2011). Furthermore, 'honour related violence' within ethnic minority communities has generated significant political interest. Debates on honour based violence remain contentious as they have generated new forms of inequality, "namely the categorization of the population of Sweden into 'Swedes' and 'immigrants' and the hierarchical ordering of these categories' (Towns, 2002:174; also see Carbin, 2014; de los Reyes, 2003). The gender equal Swede is now juxtaposed to the gender-unequal immigrant. Whilst others have suggested how prevailing cultural norms sanction various forms of violence against immigrant women (Björktomta, 2012, Eldén, 2011), we would contend that there is nevertheless a dearth of in-depth studies on symbolic violence.

\section{Methodology}

The empirical research with conducted by the second-author with women who have experienced sustained physical, sexual, and/or psychological abuse in the county of Östergötland in Sweden . The interviews are part of a larger study that explored recovery processes after violence and abuse in terms of 'coping' and 'meaning-making' of abusive experiences. On average, each 
interview lasted 1 hour and 45 minutes. The participants were invited to take part in the interview through a three-step-selection. Step one consisted of a population-based random sample of women between the ages of 18 and 60 years from the population register in the county of Östergötland (Wijma et al., 2007; AUTHOR, 2007 ). Step two entailed a randomly selected sub-sample of the women who participated in step 1 , and of these, 50 women with very diverse experiences of violence at any stage in their lives (e.g. being bullied at school, violated by an intimate partner) were selected through purposeful selection and invited to take part in the indepth interview study as part of step three.

In order to lessen any potential emotional harm, all participants were given detailed information about the purpose of the research and they were reassured that they could withdraw from the research process at any point that they wished to do so (Ellsberg and Heise, 2002). We use pseudonyms to further protect the identity of the participants. For the purpose of this paper, the interviews were transcribed from Swedish into English by the second-author. In this paper, we draw on seven of the most compelling of the in-depth interviews. The respondents referred to in this paper are White, Swedish, heterosexual women between the ages of 20-53. In terms of our sample, there are a number of interrelated points that are worth noting. First, whilst we fully acknowledge that this paper is based on a relatively small sample, we do not seek to make empirical generalisations about violence against women in Sweden. Rather, our purpose is to complement and extend current understandings into the workings of violence against women through the symbolic violence lens. Second, these interviews were conducted within a specific time and space, which therefore alerts us to the situational nature of the findings. Third, interviews as a research method can provide knowledge that reaches beyond the individual 
perspective and make social structures and collective processes available through individual narratives. Narratives are never 'direct accounts' but rather discursively constructed.

\section{Symbolic Violence}

The concept of 'symbolic violence', which was to inform Pierre Bourdieu's wider theorizing on power and domination, was developed to explain how social hierarchies and inequalities are maintained less by physical force than by forms of symbolic domination. Bourdieu (2001a) defines symbolic violence as a form of violence that is 'exerted for the most part...through the purely symbolic channels of communication and cognition...recognition or even feeling.' (2001a: 2). Systems of symbolism and meanings are imposed on groups or classes of people 'in such a way that they are experienced as legitimate' (Jenkins, 1992:104). Thus the gradual acceptance and internalisation of ideas and structures that tend to subordinate certain groups of people, masks the underlying power relations (also see Connolly and Healy, 2004). For example, the dominance of men is legitimated as the natural 'order of things', in which women are 'consigned to inferior social positions' (Bourdieu and Wacquant, 1992:168 \&173).

Symbolic violence is imperceptible, insidious and invisible. Invisibility constitutes an effective tool of silent domination and silencing the dominated. Dominant discourses often work to silence all other peripheral or subaltern discourses. Silence is not overcome simply by allowing the subaltern to speak or for them to voice their concerns; such acts are futile in overcoming the

silence. Rather systemic/structural change needs to take place to ensure that they are actually heard and accorded agency (Bhambra and Shilliam 2009). It is about identifying the structural 
complicity in silencing particular sections of society. Along with recognising the workings of institutional silencing, Bhambra and Shilliam (2009: 6) suggest that, 'silencing also operates in the very construction of our reality by framing dialogues of inter-subjectivity' so that one particular voice becomes monolithic and thus naturalized. Language itself is a form of domination. Language can constitute violence and be co-constituted by it. Language includes and excludes, it frames discourses through which social reality is constructed, and consequently has implications for power. For example Bourdieu (2001b: 246) explores how journalists frame debates and news items on television by using mobilising a particular language that often sensationalises news stories. He argues that viewer only gets to see a particular socially constructed reality that is in itself the exercise of power, or, as he puts it, symbolic violence whereby 'violence is wielded with tacit complicity between its victims [the viewers] and its agents'.

Domination that arises from symbolic violence is less a product of direct coercion, but more as a product of when those who are dominated stop questioning the order of things; stop questioning existing power relations as they perceive the world and the state of affairs in a social activity as natural, a given and unchangeable. Yet, at the same time, individuals do not question their own role in the production and reproduction of domination and subordination (Bourdieu, 1977; Bourdieu and Passeron, 1977). Symbolic violence and domination is exercised over individuals through everyday social habits, and is generated through the 'subtle inculcation of power relations upon the bodies and dispositions of individuals' (McNay, 1999:99). Therefore, symbolic violence can occur through the mundane processes and practices of everyday life. 
In this paper, we do not want to create a dichotomy between physical and symbolic violence, and nor do we want to undermine the importance of interpersonal direct violence. Instead we suggest that in specific social fields, within and outside the home, both forms of violence can and do coexist simultaneously. As Bourdieu emphasized, we need to 'overcome the opposition between a physicalist vision of the social world that conceives of social relations as relations of physical force and a "cybernetic" or semiological vision which portrays them as relations of symbolic force, as relations of meaning or relations of communication. The most brutal relations of force are always simultaneously symbolic relations' (Bourdieu, 1998: 52-53). Krais (1993) understands these distinctions in terms of 'elementary' and 'complementary' modes of domination. Elementary modes of domination are relations of domination 'made, unmade, and remade in and by the interactions between persons' (Bourdieu, 1977: 184). However, these interactions, Krais argues, have to be understood along with 'complementary' modes of domination, which are invisible such as the domination of particular institutions and discourses that may seem to be neutral, apolitical and impartial, but are in fact intersected by particular forms of racialized/ethnicized, gendered, classed power relations and structures. Thus elementary modes of domination (physical violence) have to be understood together with complementary modes of domination, namely symbolic violence (Krais, 1993). Bourdieu supports this by suggesting that whenever overt physical and economic violence is negatively sanctioned or meets with collective reprobation, symbolic violence, 'the gentle invisible form of violence' becomes the most safe mode of domination (Bourdieu, 1977:192). Thus symbolic violence lacks the intentional and instrumental quality of brute and coercive physical force and instead, 'works not directly on bodies but through them' (Topper, 2001:47). It is for this reason that in some instances women recognise physical violence as more tangible because it often results in 'scars' 
which potentially 'heal'. In contrast, symbolic violence is often more difficult to recover from because of the way in which it works on the body. For example, Kristina, a 20- year- old respondent said, 'When he [her father], I kind of felt that it was nice that it hurt physically. It is easier to handle the physical pain...than to listen to him saying how useless I am'.

\section{$\underline{\text { Misrecognition }}$}

Misrecognition is the process whereby power relations are perceived, "not for what they objectively are but in a form which renders them legitimate in the eyes of the beholder' Bourdieu and Passeron, 1977: xiii). Legitimation of the social world results from social agents taking the world for granted, accepting it as it is; since their 'cognitive structures' (perceptions) are 'issued out of the very structures of the world' which tend to picture the world as evident. Thus practices that would ordinarily be deemed as problematic or 'violent' eventually gain social acceptance through, for example, particular, discourses, practices and policies. In expanding Bourdieu's conceptualisation of 'misrecognition', Burawoy(2012: 189) recognises 'misrecognition as deep and universal - the result of the incorporated and embodied habitus, a process of internalizationthat was unconscious rather than a spontaneous effect of specifically capitalist relations'.

With reference to the co-existence of physical and symbolic violence in the same social formation and sometimes in the same relationships, Bourdieu (1977: 191) argued that 'when domination can only be exercised in its elementary forms, i.e. directly, between one person and another, it cannot take place overtly and must be disguised under the veil of enchanted 
relationships...in order to be socially recognised it must get itself misrecognised'. Drawing on the example of the North African Kabyle society, Bourdieu explains that the only way in which relations of domination and exploitation can be maintained (for example, between the khammes and his master) is through the cultivation of relations of personal dependence which must be, 'disguised and transfigured lest they destroy themselves by revealing their true nature; in a word, they must be euphemized'. Euphemization would take expression in acts such as taking care of the khammes son, marrying of his daughter and giving him presents (Bourdieu, 1998). Bourdieu illustrates this through the examples such as the gift exchange in the Kabylia society where 'giving is also a way of possessing', because in the absence of any juridical guarantee or any coercive force, one of the few ways of "holding" someone is to keep up a lasting asymmetrical relationship such as indebtedness; and because the only recognised, legitimate form of possession is that achieved by dispossessing oneself - i.e. obligation, gratitude, prestige, or personal loyalty' (Bourdieu, 1977:195). Thus the exchange of goods is constitutive of symbolic violence through which an 'interested relationship is transmuted into a disinterested, gratuitous relationship' (Thompson, 1984:56). The subjective misrecognition of the meanings associated with a particular action, practice or ritual can become a necessary condition for symbolic violence.

In the specific context of interpersonal violence, often the perpetrator tries to 'hold' onto someone through similar strategies so that the indebted adopts an obsequious attitude (Thompson, 1984). In other words, it is about creating dependency. For example, in situations where violence has occurred, often the perpetrator indulges the victim with gifts, such as flowers, chocolate and dinners, and a certain levels of intimacy is often re-established. This is about 
creating misrecognition through processes of punishment and reward so as the two become almost indistinguishable for the victim. This also can compel the victim to allow the perpetrator back in the house, and force her to see the relationship as 'normal'. Thus misrecognition is the fact of 'recognising violence which is wielded precisely inasmuch as one does not perceive it as such' (Bourdieu and Wacquant, 1992: 168).

For instance, Lena, a 45-year-old respondent, had been with her husband for 10 years when she met another man with whom she fell in love. She left her husband and four children to live with the new man, but soon found herself in a very violent relationship. In the example, in Lena's case we can see how strategies adopted by her violent partner resulted in her misrecognising the reasons behind the violence she endured:

'It was devilishly clever, because in this way... he beat me and pushed me away and then he, well, gave me a little love, and it became sexual as well. So he gave me a little love and a little sexual tenderness, and then he beat me again. And this pushing away and pulling back, it breaks you down in a terrible way, because after a while you have no trust at all.'

Women who supposedly feel love and/or 'sexual tenderness' by their abusers often fail to recognise the power relations at play because they understand their relationships to be 'enchanted', 'romantic', 'the way it's meant to be' (see Bourgeois, Prince and Moss 2004). In 
their study with young women who inject drugs in San Francisco and are in violent (physical, sexual and emotional) relationships with men, Bourgois, Prince and Moss (2004: 259) note that " "everyone wants to be in love with someone" [...] Romantic love [...] becomes a central mechanism of the symbolic violence that misrecognizes male domination and violence again women and renders it the woman's fault'. In Lena's case, her violent partner through intermittent acts of 'love' created a sense of indebtedness, dependency and gratitude in Lena. Indeed, when the physical violence had subsided, this strategy worked to further subdue her and strengthen the traumatic bond between her and the perpetrator (Enander and Holmberg, 2008). Lundgren (1991) understands internalization as being part of the 'normalization process', where the violated woman, or any individual, gradually adapts to the abuser's demands in order to avoid further violence. The objective of the use of violence is to negate the agency and voice of the abused, whilst simultaneously emphasising the victim's personal shortcomings - i.e. that she/he has done something wrong and was being rightly punished. One of the consequences of this is that violated women begin to view the relationship through the eyes of the abuser and gradually lose their 'own voice' and perspectives in such relationships. Frequently victims are uncertain and confused as to what exactly is happening to them and, as a result, become unable to articulate for themselves what they are experiencing to others.

Likewise, misrecognition of cause and responsibility for violent acts underlines how a 'blaming the victim discourse' is not simply a socially accepted aspect, but rather recognised as a given feature of the world. For instance, Siri, a 45-year-old respondent, recounted how five older men raped her and her friend when she was 14 years old and drunk. Afterwards Siri and her friend went home and never talked about what happened. Siri felt very ashamed about what had 
happened and blamed herself, particularly because she had been drinking illegally. She said, 'I was so sure that it was all my own fault'. Moreover, she never told her parents about the rape because 'her father would have been angry with the boys, but at the same time disappointed with having a 'loose' or 'dissolute' daughter, and [her] mother would have cried and felt sorry for [her] but also very sorry for herself'. In this instance, male violence is misrecognised and legitimised as 'natural' and as a consequence for women who engage in what is considered to be 'indecent', 'inappropriate' or socially unacceptable behaviour. Such problematic discourses meant that Siri and her friend were silenced from ever reporting the crime to the authorities and their parents.

Similarly, in reflecting on the sexual abuse that she encountered during her childhood, Petra, a 26-year-old respondent, also identified processes of misrecognition that normalised and 'made acceptable' the abuse that she experienced at the hands of her maternal grandmother's partner. She describes telling her mother about the abuse that she was subjected to:

'It started when I was young. My (maternal) grandmother's partner molested me. And it was very, you know...difficult. It took time before I told...I told my mother. It was like not penetration with his sex organ, but still with his fingers and, well...he...well, he went down on me for oral sex. And then he always left...put some money on the table and then he left. And when I did tell my mother, she...well, she said: "well, yes, but he has tried that with me as well and with my sister when we were young".' 
Interviewer: 'When you told your mother, was that while the molestation was still ongoing?'

Petra: 'Yes, I told her once when we were there. It had been going on for three or four years then. I'd rather not be left alone there - and mum and she [grandmother] were going shopping which meant I was to be left alone. So then I told her and it was like she kind of stopped still for a while. And that kind of...well, after that she was a bit more...tied to me. And she didn't fully leave me out of sight'.

Petra's disclosure of the abuse was partly acknowledged by her mother through her stronger physical proximity to Petra. However, the abuse could not be spoken about, not recognized as such - rather it could only be acknowledged through an act of misrecognition. Petra's mother did acknowledge that Petra has been subjected to an unpleasant act. However, it is to be understood as an act that is part of the grandmother's partner's behavioural repertoire (as Petra's mother has also encountered similar abuse) and one can but try to avoid it/him. With Petra's mother, there is a process of normalization at play here, rather than condemning and challenging what went on, it she took practical steps and become more vigilant, such as not letting Petra out of her sight when the perpetrator was around.

Such dynamics of misrecognition also operate in public spheres as well, including in supposedly protected social fields, such as the school. In describing the abuse that she endured at school, Kristina explained that, 'When we had breaks at school, the boys pulled me into the toilets and took off my clothes and touched me and also forced me to touch their sexual organs'. On being 
asked whether she had informed a teacher, Kristina responded: 'I told the teacher about the boys. The teacher just said 'you understand that the boys do that only because they like you'. In this case, the teacher, who embodies symbolic capital and, thus, symbolic power, '[has] obtained sufficient recognition to be in a position to impose recognition' (Bourdieu, 1989: 23). Here symbolic power has to be understood in and through a given relation between those who exercise power and those who submit to it, i.e. in the very structure of the field in which belief is produced and reproduced... what creates the power of words and slogans...is the belief in the legitimacy of words and of those who utter them' (Bourdieu, 2002:170). The teacher embodies the power of the institution and has the symbolic power to 'make things with words' and stands as the 'substitute for the group (from which they receive, in return, their power) which exists only through this delegation and which acts and speaks through [her]...' (Bourdieu, 1989: 24). Power operates is through subjective misrecognition of the meanings implicit in the action, practice and ritual, and '[a]ny language [the language of the establishment] that can command attention is an ''authorised language'...' (Bourdieu, 1977:170 \&171) and thus legitimate. The authorised language silences other voices in the narrative- through misrecognition. In Kristina's case, the teacher had the power and authority to recognise Kristina's experiences at the hands of the boys as abuse, but decided not to. As mentioned above, this demonstrates how to recognise/misrecognise is in itself an act of power. By deciding to misrecognise, particular silences are produced and reproduced and particular narratives about what is considered to be right and wrong are legitimised. Consequently, the teacher legitimised and created a belief in Kristina that the conduct of the boys was acceptable because it was an expression of them 'liking' Kristina. The teacher did not see it as abusive or exploitative, but as a demonstration of 'affection' of the boys towards Kristina. Kristina in turn said that she was 'drawn to the boys 
because at least they talked to me and as the teacher had said that they did that because they liked me...I started to think that perhaps it was like that...perhaps they liked me'. Problematically, the trade-off for being liked, being spoken to and to be popular with the boys was to be abused by the same boys. Whilst Kristina accepted the teacher's explanation, the experience also raised many other complex issues. On the one hand, she believed that the boys touched her sexually because they liked her. This can be explained by what Bourdieu refers to as the 'magical frontier between the dominant and the dominated', through which the dominated unknowingly and unwillingly, 'contribute to their own domination by tacitly accepting the limits imposed, often take the form of bodily emotions - shame, humiliation, timidity, anxiety, guilt - or passions and sentiments - love, admiration, respect' (Bourdieu, 2001a: 38). On the other hand, Kristina expressed disgust with her body - 'having breasts and...like rounded hips'. It was 'not like it was my body' as it 'belonged to the boys'- 'the subterranean complicity that a body slipping away from the directives of consciousness and will maintains with the violence of the censures inherent in the social structures' (Bourdieu, 2000:170).

The misrecognition of domination and subjugation intensified Kristina's anxiety and she sought control through self-harming.

'In secondary school, I sometimes cut myself and sometimes, I put needles in myself when I felt really bad. I cut only where it would not be visible and once or twice I went out in the snow and lay down with just my underwear. It is as if the physical pain lowers the anxiety...' 
Seemingly, self-harming lowered her anxiety. Indeed, on one occasion, she even poured hot wax over her fingers to deafen her anxiety. As Klonsky and Muehlenkamp (2007:1049) argue, 'selfinjury is most often performed to temporarily alleviate intense negative emotions... and help resist suicidal thoughts. We argue that there is more at stake here than one might think, namely the insidious intertwinement of overt and covert violence, of elementary and complementary modes of domination, that becomes 'misrecognised' as an individual/personal act of self-injury, which, in turn, both individualises the problem and medically pathologies the individual. In other words, the individual's narrative becomes supplanted by an official narrative, which puts the onus on the individual and, consequently, absolves the responsibility of others (perpetrator(s), i.e. the state and its institutions). With no sheltered space to help her create a sense of safety around herself, neither at home nor at school, Kristina was left with little option but to take refuge in what could be described as the promise of the limit, that is the relief provided by the experience of momentary and finite physical pain - thus drawing a (temporary) border between herself and the unbounded violence. Scaer (2001) has discussed the role of boundaries and boundary breaking in trauma. Through individual experiences, we form psychological boundaries around ourselves. As a child, the caregivers provide the principal safety boundaries, which functions as a safe haven for the child when unpleasant things happen. As adults, our abilities to safeguard ourselves are more firmly established and one can more easily handle unsafe situations by oneself, but significant others are still an important resource for upholding the sense of safety, especially in situations where one feels insecure, vulnerable or helpless. The abusive acts inflicted by Kristina's father, who, as a significant other, should function as a primary source of safe boundary formation for her, displaces the boundaries that are essential for 
emotional security, thus making Kristina more vulnerable to the explanation imposed by the teacher.

\section{$\underline{\text { Strategies of Condescension }}$}

Strategies of condescension refer to social practices in which a person or group of people (for example, the ethnic majority), with greater power, distort or minimize power disparities between themselves and people who occupy relatively subordinate positions within a given social space, or through the manipulation of relational proximity when it is to their advantage. Such a strategy works well if those who occupy a higher position in the hierarchy and have greater access to symbolic capital recognize the disparity between themselves and the rest 'so that the symbolic negation of the hierarchy...enables the speaker to combine the profits linked to the undiminished hierarchy with those derived from the distinctly symbolic negation of the hierarchy' (Bourdieu, 2002:68). They symbolically deny the social distance between themselves and the others, 'a distance which does not thereby cease to exist, thus reaping the profits of the recognition granted to a purely symbolic denegation of distance...' (Bourdieu, 1989:16). Through language, more specifically, 'legitimate language' we can exercise our social competence, our social power, and impose our authority. In discussing the symbolic power exerted through language, Bourdieu (2002) describes how the mayor of the French province of Bearn, in a speech to assembled Bearnais, chose to speak in the provincial language rather than 'official' French. Bourdieu describes this as a strategy of condescension, which achieves its value for the instigator through a dual motion of negation and simultaneous reinforcement of known power structures - i.e. the audience recognize the unwritten law, which prescribes French as the only acceptable language 
for formal speeches in formal situations. Those who subvert objective hierarchies are those who are confident of their position in these hierarchies and possess the legitimate competence and the necessary symbolic capital.

In institutional settings such as the hospital, schools or universities, whilst there may be institutional equality between doctors and nurses, teachers and students, ethnic minority and white majority university employees in that they are supposedly equally valued and instrumental in the success of their environment, in reality, nevertheless, there is 'real' social distance between them. Only some forms of speech are accredited, 'worthy of being believed' and this is often accompanied by other non-linguistic properties such as academic titles, 'all of which place the legitimate speaker in a pre-eminent position' (Bourdieu, 2002:70; also see Perez, 2004).

For example, Lena was examined at the hospital emergency ward, twice in connection with suicide attempts and once when she experienced a 'bodily collapse...with strange perspirations, numbness, nauseous and breathlessness'. When she was admitted, her 'whole back was full [of bruises], because [she] had been thrown down the staircase a couple of times - so that [she] looked as if someone had gone over [her] back with a baseball bat, but they [hospital staff] did not ask'. Lena stated that when the doctor examined her, the husband was present and 'he did the talking, and he said that it was a reaction from her separation from (her) my children'. Vodde (2002: 75) argues that 'any statement defining the other or one's relationship with the other, is considered a statement that attempts to define, unilaterally one's position of authority with that person. Vodde (2002: 76\& 77) states that 'the more one partner is situated within power 
trajectories in social space, the more he/she will most likely control the interactions within the relationship while obscuring or normalising such control'. Thus the capacity to manipulate is greater, the more capital one possesses in relation to the abused. On being asked whether Lena had an opportunity to speak to the doctor on her own, she responded: 'No, he [her husband] was there all the time. The psychologist came and, because they apparently do after a suicide, and she sat beside me but she spoke to him. She did not talk to me.' Thus as Bourdieu suggests these interactions cannot be seen as a 'closed world' rather that the whole 'social structure' is present in each interaction (Bourdieu, 2002:67).

Lena's husband can be seen as symbolically supporting the wife by sitting by her side, holding her hand (symbolic negation of hierarchy), but the social distance that is reduced only serves to reinstate the power hierarchies. Here the relational proximity is exploited because it is seen as advantageous. Furthermore, the husband took the opportunity to talk to the doctor and thus carve a 'story' around the on-going abuse, which the doctor accepted as fact. As we are aware, women who experience abuse may not necessarily disclose information in the first meeting with medical staff and it might need repeated requests and time before details are eventually disclosed. Interestingly, with her injuries being explained in terms of suicide, it serves only to legitimise Lena's husband's narrative. Lena was constructed as vulnerable, irrational, unstable, and in need of medical intervention for her own safety. The medical staff became dependant on the husband which in turn co-constituted him as caring, competent, dutiful and rational. Crucially, he became the important interlocutor between Lena and the hospital staff and, as a result, he was able to orchestrate any narrative that he wished to in terms of how the injuries were sustained and the apparent state of Lena's mental health. Indeed, he is able to manipulate the proceedings in the 
hospital so that the official medicalised narrative of the hospital further silences Lena, which sees her as someone in need of help and an intervention, that she posed a threat to herself and not by her husband. So both Lena's husband and the hospital worked to silence Lena's voice and agency, even though she is the victim in this situation. As discussed by Fiske (1993), power encourages stereotyping others. The powerless need to be attentive to those in power as they control the outcome, whereas the powerful don't need to attend to the powerless and, thus, are more likely to stereotype the less powerful which would have repercussions on the outcome of the interaction. Similarly, Karin, a 34-year-old respondent, disclosed that she and her mother were beaten and psychologically abused by Karin's father. Karin and her mother separated from her father just before Karin turned 16 years-of-age and she went to live with her maternal grandmother for some time during that period. She mentioned that her gymnasium teacher was extremely sympathetic to her situation. She talked with her teacher and told him that, 'I have a tough time at the moment, for...I, it was just about the time we were about to move [to her grandmother] and it was chaos, and I wanted to be excused as I had not had time to do a school assignment'. Her teacher appeared to be sympathetic and frequently enquired about her wellbeing. In doing so, he was perceived by Karin as an understanding friend, thus displacing the student-teacher institutionalised hierarchy. Bourdieu argues that the dominant might embrace the language of the dominated as a token of his concern for equality through a strategy of condescension, by temporarily but ostentatiously abdicating his dominant position in order to 'reach down' to his interlocutor, 'the dominant profits from this relation of domination, which continues to exist, by denying it' (Bourdieu and Wacquant 1992:143). But then at the end of the term, Karin continued, 'when we were going to get our grades, all of a sudden he said that you only get a 3 [average grade] because you did not do that assignment. It was just like a smack 
again [hinting about previous abuse that she had endured at home], and I felt that all trust in this adult vanished. Thus, in a way, one was not taken seriously, and it made one feel that I would not talk to anybody at all after that'.

What both of these cases highlight is the way in which formal institutions can work in particular ways to silence the victims of abuse. Particularly in Lena's case, the abuser was able to obtain a privileged position with the medical practitioners and was able to set in motion the narrative that he had concocted whilst on the way to the hospital with Lena. He was able to avert any suspicion of abuse by performing the role of a benevolent and caring husband who only had the best interests of his wife at heart. It is rather surprising that the hospital did not treat Lena as an adult (an agent in her own right) and give her the space to talk freely away from her husband. In both cases, the institutions compounded Lena and Karin's abuse and prolonged their silence.

\section{Consent/ Complicity}

Finally, consent and complicity relate to the way the social order is inscribed on the body through the learning and acquisition of dispositions. Bourdieu understands complicity as neither a 'passive submission to an external constraint' nor a 'free adherence to values' (Bourdieu, 1992: 168). Instead a person subjected to symbolic violence acquires an attitude that does not so neatly fall within the ordinary categories of freedom or constraint. Thus, in relation to symbolic violence, these concepts refer to the "coercion which is set up only through the consent that the dominated cannot fail to give to the dominator (and therefore to the domination) when their 
understanding of the situation and relation can only use instruments of knowledge that they have in common with the dominator, which, being merely the incorporated form of the structure of the relation of domination, make this relation appear as natural...' (Bourdieu, 2000:170).

In referring to consent, however, Bourdieu is not suggesting that individuals are willingly and knowingly putting themselves in positions where they may be open to abuse. The point is, as Krais (1993: 172) notes, that while an individual may be able to 'decode the relevant signals and to understand their veiled social meaning' this is 'without recognizing them consciously as what they are - namely as words, gestures, movements and intonations of domination'. The state of compliance is not a 'voluntary servitude' that is consciously granted. Rather 'it is itself the effect of a power, which is durably inscribed in the bodies of the dominated, in the form of schemes of perceptions and dispositions (to respect, admire, love), in other word, beliefs which make one sensitive to certain public manifestations, such as public representations of power' (Bourdieu, 2000:171). For example, through the symbolic power structured on gender, disapproving looks and remarks made by a male partner can convey the message that a woman is not behaving the way she should. Consequently, through misrecognition of her own behaviour as, for example, not being 'feminine enough', the woman may change her behaviour and thereby comply with the exerted domination. Such insidious acts of domination often mean that many victims make exceptions and accept acts of violence as situations brought about by themselves. As described by Lundgren (1991), in the 'normalisations process' the abused woman gradually adapts to the demands of the abuser as a way of avoiding violence. However, this adaptation also leads to a change in her perception of the situation and, gradually, to her internalising the 
abuser's explanations for the violence. Lundgren's emphasis on non-blame of the abused woman is similar to the Bourdieu's analysis of the 'submissive dispositions that are sometimes used to blame the victim are the product of the objective structures, and also that these structures only derive their efficacy from the dispositions which they trigger and which help to reproduce them.' (Bourdieu, 2001:40). Two ideas are intertwined. First, the paradoxical nature of social practices and social spaces created for women in violent relationships is such that while they resist the lived experiences and norms, they also subject themselves to these norms. This is often manifested in women commenting on the loving and kind nature of their 'violent' partners but which only gets transformed into something else during a conflict. Second, even though women recognise that they are subjected to some form of a power relationship, it is not until they are away from the abusive situation that they truly recognise it for what it was.

For example, Lena reflected on how she was never obsessed with her body but 'it could start with him saying "are you really going to have that cake", and then I thought that no, but of course I should not, I might become really fat. And then he would not say anything more but it left me with this feeling that something is not right'. Furthermore, in describing an incident from a New Year's Eve party, which was the first time he beat her, Lena stated that 'he thought that I had not behaved the way he had expected. And I have always thought that I have behaved well but I forgave him. I thought that he is not feeling well and it's hard for him to move together with me because it's dramatic for him with the children coming every second weekend, it's so much change for him. So I found so many excuses for him to beat me.' 
These perceptions also shaped her interactions with the institutions, such as the hospital. During a visit to the hospital emergency ward, Lena, stated:

'I and this person [the perpetrator] thought that I had had a heart attack, but they could not find anything wrong....and they kind of decided that it was stress and I did not tell them about the situation at home...so they decided that it was work that was very stressful and they bought it and I bought it and then I went home.'

At the hospital, she adopted the explanation given to her rather than questioning it, 'they bought it and I bought it and then I went home'. Lena, in a vulnerable help-seeking situation, complied with the caregiver's explanation, the 'official point of view [...] expressed in official discourse' (Bourdieu, 1989: 22), while at the same time communicating a certain awareness of doubt towards the given explanation. This doubt, however, has no space in the official dominant language and cannot be expressed without challenging the symbolic capital of the hospital staff as well as of the husband. In some way Lena bought the situation to maintain peace.

As with misrecognition, we would like to point out that women despite the emotional, psychological and sometimes even physical violations, often fail to recognise the 'enchantment' of the relationship. This enchantment, we would argue, allows the victim to internalise the perpetrator's world-view and make excuses for the perpetrator's behaviour. As illustrated by her comments, Lena recognises that she was subjected to some form of exercise of power, yet it was not until she was away from the abusive situation that she was able to fully recognise it for what it was. 
The complex interplay between misrecognising and involuntary compliance are evident in the experiences described by Rita, a 43-year-old respondent, who lived with her violent partner for 10 years when she was younger. Her partner beat her regularly when he was drunk. Rita described how she was cautious and ever vigilant every time he came home drunk. On such occasions, her partner would often caress her and say ‘honey, you aren't afraid that I would beat you, are you?' Then he would beat her up. These episodes of violence were wholly unexplainable for Rita. As her partner could also be very nice and charming, she spent a lot of time trying to understand why the violence occurred when it did and what pre-emptive measures she could take in order to prevent these situations from arising. When asked if others knew about the abuse she endured, Rita said that in the main her partner was seen as nice and charming by most people, although some of her friends and parents probably did know about the abuse. In fact, even the police had been involved once early on in the relationship. On one occasion, he beat her up very badly, but she managed to lock herself in the bathroom and escape through the window. She ran to a nearby house to borrow the phone to call her parents. She stayed with her parents that night. Due to the shocking events of the night, she still is not quite sure who informed the police. The next day her partner apologised and said it would never happen again and asked for forgiveness. Rita said that her parents forgave him. During the remainder of their relationship, Rita did talk to her mother periodically in order to receive some comfort and support. Her friends never brought up the subject nor mentioned the bruises she often had. In this case, Rita's partner's violent behaviour tended to be misrecognised as the nasty effects of alcohol on an otherwise nice, decent guy. Indeed, there was a general compliance with the situation - 
her mother comforted her through 'bad episodes' and friends 'tactfully' avoided talking about 'the problem'.

There are similarities with the narrative of Iris, a 53-year-old respondent, who was twice badly beaten by her husband. Her husband had consumed alcohol in combination with painkillers on both occasions and had no memory of the beatings afterwards. When Iris talked to him about the violence and showed him her broken glasses and a large visible scar on her face (still visible today), he still would not believe that he had caused it. Iris stated:

'He has no memory of it happening. And I believe it to be the best for him, not remembering what happened. He hardly dares to hurt a fly. He was unemployed, had aches and pains in his body. Then it often happens that they have some, well, and he didn't think and then he had some drink. And well, the drink together with these pills [painkillers] makes it twice as, four times as bad as it needs to be'.

Iris blamed the alcohol rather than her husband for his loss of control and for becoming 'another type of person'. These excuses/reasons, in general, seem to have become an integral part of the way society views violent behaviour in general - and men's violent behaviour in particular. However, alongside the suggestion that men experience decreased self-control as a result of alcohol, comes the idea that women need to adapt, modify their own behaviour or be sympathetic, whether or not they are the ones doing the drinking (Author, 2010). 
The social space, which is occupied by both the abuser and the abused, constitutes a field in which multi-layered intersectionalities of experiences are mapped out. Ways of conducting life are almost always perceived, even by dominated subjects, from the limiting and reductive points of view of dominant perspectives. These experiences are constitutive of knowns and unknowns in the sense that they are apprehended but not given any significance in the official discourse, and, thus, remain as a known unknown within the subject. The official discourse imposes a point of view- that of the institution, and which is recognised as the legitimate vision of the social world (Bourdieu, 1989).

\section{Conclusion}

Our discussion demonstrates that the mechanisms of symbolic violence produce, reproduce and legitimate power relations in everyday practices of agents. Arguably, symbolic violence, despite its virtual invisibility, creates the conditions of possibility for other more tangible and visible forms of violence. We demonstrate this through three Bourdieusian mechanisms: misrecognition, condescension and complicity/consent. Misrecognition and condescension enable us to understand that power relations are perceived not for what they objectively are, but in a form that renders them legitimate. From the discussion of consent/complicity, it can be argued that there is an implicit suggestion, in our paper, of a) women's apparent acquiescence to masculine domination and power and b) women's own complicity in their victimization. To talk about complicity in relation to any form of violence, but particularly violence against women is, of course, highly contentious as it would appear that the suggestion is that women allow themselves to be passive recipients of violence and ties in with many of the myths about sexual and domestic violence such as, 'she asked for it' or 'some women seek out abusive relationships'. However, 
this is not our objective. What we want to emphasise is that an individual in a situation of violence is often unable to recognise consciously the subtle intonations of power and domination, which are legitimised and rationalised as 'normal'. Thus the dominated and the dominant can share the same understandings of the world. Symbolic violence engenders uncomfortable feelings which are so difficult for its victims to pin down and yet is part of what makes their lives so miserable. Certainly for those women who love and feel loved by their abusers despite the emotional, psychological and physical violations they experience yet often initially fail to recognise, it does appear that they perceive their relationship as 'enchanted', at least initially. It is some of these complexities that we would like to address through this concept.

Finally, any discussion on violence begs an accompanying question: how do we move forward? Dominated agents can potentially resist power relations and break the symbolic violence that they endure in their everyday lives. Indeed as the struggles of everyday life have certain degree of autonomy from the structures in which they are embedded, they can open up spaces for contestation. All the women in this article managed to use the available resources, while simultaneously creating a space for dialogic understandings of their situation and developing new 'turning points'. In doing so they also disrupted the habitus which reproduced their domination. Iris never told anyone but eventually confronted her partner, left him and built her own life. Lena decided to work close with the police. Kristina left home, moved into her own apartment and started university. For Rita the change came when she saw the effects that the violence had on her children. Siri joined a feminist group as a young adult and used this platform to speak about men's violence against women. Karin started to see a therapist as an adult. The commonality between the experiences of these women is that eventually they recognised the 
violence which they had misrecognised as 'natural' by moving beyond the structures which had shaped their embodied dispositions.

\section{WORD COUNT: 8980}

Acknowledgements: We would like to thank GEXcel (Centre of Gender Excellence) for providing the research environment to develop this paper. To Professors Nina Lykke and Barbro Wigma for giving us the opportunity to be GEXcel scholars. A special thanks to Prof. Franca Bimbi, Angela Toffanin and Guilia D’Odorico at Padova University, Italy and to Professor Margrit Shildrik at Linköping university for their invaluable and generous comments on our presentations. 


\section{Bibliography}

Alcoff, L. and Gray, L. (1993) ‘Survivor discourse: Transgression or recuperation?’ Signs, Vol. 18, No. 2: 260-290.

Bhambra, G. and Shilliam, R (2009) Silencing Human Rights: Critical Engagements with a Contested Project, London: Palgrave MacMillan.

Björktomta, S-B. (2012) Om patriarkat, motstånd och uppbrott - tjejers rörelser i sociala rum. [Patriarchy, resistance and breaking up - young girls' movement in social spaces]. Doctoral thesis, Department of Social Work, Faculty of Social Sciences, University of Gothenburg, Sweden. URI: http://hdl.handle.net/2077/29076

Bourdieu, P. (1977) Outline of a Theory of Practice Cambridge: Cambridge University Press.

Bourdieu, P. and Passeron, J. (1977) Reproduction in Education, Society and Culture, London: Sage.

Bourdieu, P. (1989) ‘Social Space and Symbolic Power' Sociological Theory, Vol. 7, No 1: 1425.

Bourdieu, P. (1998) Practical Reason: On the Theory of Action, Cambridge: Polity Press. 
Bourdieu, P. (2000) Pascalian Meditations, Cambridge: Polity Press.

Bourdieu, P. (2001a) Masculine Domination, Cambridge: Polity Press.

Bourdieu, P. (2001b), Television, European Review, Vol. 9, No. 3: 245-256.

Bourdieu, P. (2002) Language and Symbolic Power, Cambridge: Polity Press.

Bourdieu, P. and Wacquant, L. (1992) An Invitation to Reflexive Sociology, Chicago: University of Chicago Press.

Bourgois, P. (2004) 'The Everyday Violence of Gang Rape' in Scheper-Hughes, N. and Bourgois, P. (2004) editors, Violence in War and Peace: An Anthology, Malden, MA, Blackwell, 343-348.

Bourgois, P., Prince, P and Moss, A. (2004) 'The Everyday Violence of Hepatitis C among Young Women Who Inject Drugs in San Francisco' Human Organization, Vol. 63, No. 3: 253263.

Burawoy, M. (2012) 'The Roots of Domination: Beyond Bourdieu and Gramsci' Sociology, Vol. 46, No. 2: 187-206. 
Burman, M. (2010) 'The ability of criminal law to produce gender equality: Judicial discourses in the Swedish criminal legal system' Violence Against Women, Vol. 16, No. 2: 173-188.

Burman, M. and Öhman, A. (2014) 'Challenging gender and violence: Positions and discourses in Swedish and international contexts' Women's Studies International Forum, Vol. 46: $81-82$.

Carbin, M. (2014) 'The Requirement to Speak: Victim Stories in Swedish Policies against honour-related violence' Women's Studies International Forum, Vol.46: 107-114.

Connolly, P. and Healy, J. (2004) 'Symbolic Violence, Locality and Social Class: the educational and Career Aspirations of 10-12 year old boys in Belfast' Pedagogy, Culture and Society, Vol.12, No.1: 15-34.

Crenshaw, K. W. (1991) 'Mapping the Margins: intersectionality, Identity Politics and Violence Against Women of Colour' Stanford Law Review, Vol. 43, No. 6: 1241-1299.

de los Reyes, P. (2003) Patriarkala enklaver eller ingenmansland? Våld, hot och kontroll av unga kvinnor i Sverige [Patriarchal enclaves or no-man's land? Violence, threat and control of young women in Sweden], Norrköping: Integrationsverkets skriftserie IV. 
Dobash, R. E. and Dobash, R. P. (1997) 'Violence Against Women' in O’Toole, L and Schiffman, J. R. (1997) editors, Gender Violence: Interdisciplinary Perspectives, New York: New York University Press.

Ekbrand, H. (2006). Separationer och mäns våld mot kvinnor [Separations and men’s violence against women]. (Doctoral dissertation). Göteborg University: Department of Sociology.

Eldén, Å. (2011) 'Rykten och tystnad. Berättelser om sexuellt våld i turkiska och svenska media' [Rumors and silence, Narratives of sexual violence in Turkish and Swedish media]. Dragomanen 13, Istanbul: Svenska Forskningsinstitutet i Istanbul.

Ellsberg, M. and Heise, L. (2002) 'Bearing witness: ethics in domestic violence research'. Lancet, Vol. 359: 1599-1604.

Enander, V. and Holmberg, C. (2008) 'Why does she leave? The leaving process(es) of battered women' Health Care for Women International, Vol. 29, No. 3: 200-226.

Enander, V. (2011) 'Violent Women? The Challenge of Women's Violence in Intimate Heterosexual Relationships to Feminist Analyses of Partner Violence' NORA-Nordic Journal of Feminist and Gender Research, Vol. 19, No. 2: 105-123.

Fiske, S. T. (1993) 'Controlling other people. The impact of power on stereotyping' American Psychologist, Vol. 48, No. 6: 621-628. 
Gill, A. (2004) 'Voicing the Silent Fear: South Asian Women's Experiences of Domestic Violence' The Howard Journal of Criminal Justice, Vol. 43, Issue 5: 465-483.

hooks, b. (1997) 'Violence in intimate relationships: A feminist perspective' in O'Toole, L. and Schiffman, J. R. (1997) editors, Gender violence: Interdisciplinary perspectives, New York: New York University Press, 279-285.

Holmes, S. M. (2013) Fresh Fruit, Broken Bodies: Migrant Farmworkers in the United States, Berkeley: University of California Press.

Hydén, M. (1995) 'Mot en förståelse av kvinnomisshandel som en social process' [Towards an understanding of woman battering as a social process], Kvinnovetenskaplig Tidskrift, Vol. 16, No 4: 67-74.

Jenkins, R. (1992) Pierre Bourdieu, London: Routledge.

Kelly, L. (1988). Surviving Sexual Violence, Cambridge: Polity Press.

Kelly, L. (1996a) 'When does the speaking profit us? Reflections on the challenges of developing feminist perspectives on abuse and violence by women' in Hester, M., Kelly, L. and 
Radford, J. (1996) editors, Women, Violence and Male Power: Feminist Activism, Research and Practice, Buckingham: Open University Press.

Kelly, L., Burton, S. and Regan, L. (1996b) 'Beyond Victim or Survivor: Sexual Violence, Identity and Feminist Theory and Practice' in Adkins, L and Merchant, V. (1996) editors, Sexualizing the Social: Power and the Organization of Sexuality, Basingstoke: Macmillan Press.

Kleinman, A (2000) 'The violences of everyday life: The multiple forms and dynamics of social violence' in Das, V., Kleinman, A., Ramphele, P. and Reynolds, P. (2000) editors, Violence and subjectivity, Berkeley: University of California Press: 226-241.

Klonsky, E. D. and Muehlenkamp, J. J. (2007) 'Self-injury: A research review for the practitioner' Journal of Clinical Psychology, Vol. 63: 1045-1056.

Krais, B. (1993) 'Gender and Symbolic Violence: Female Oppression in light of Pierre Bourdieu's theory of social practice' in Calhoun, C., Lipuma, E. and Postone, M. (1993), editors, Bourdieu: Critical Perspectives, Cambridge: Polity Press: 156-177.

Lamb, S. (1996) The Trouble with Blame: Victims, Perpetrators and Responsibility, Cambridge, Massachusetts: Harvard University Press. 
Lamb, S. (1999) 'Constructing the Victim: Popular Images and Lasting Labels' in Lamb, S (1999) editor, New Versions of Victims: Feminist Struggles with the Concept, New York: New York University Press: 108-139.

Loseke, D. R. (1999) Thinking about social problems: An introduction to constructionist perspectives, New York: Aldine de Gruyter.

Lundgren, E. (1991) Våldets normaliseringsprocess: två parter - två strategier [The process of normalising violence: Two actors - two strategies], Stockholm: Riksorganisationen för Sveriges kvinnojourer.

Lundgren, E., Heimer, G., Westerstrand, J. and Kalliokoski, A. (2001) Slagen Dam: mäns våld mot kvinnor i det jämställda Sverige - en omfångsundersökning [Captured queen: Men’s violence against women in "equal" Sweden: a prevalence study], Umeå: Brottsoffermyndigheten.

Maynard, M. (1993) ‘Violence towards women' in Richardson, D. and Robinson, V. (1993) editors, Introducing women's studies: Feminist theory and practice London: Macmillan.

McNay, L. (1999) 'Gender, Habitus and the Field: Pierre Bourdieu and the Limits of Reflexivity' Theory, Culture and Society, 16: 95-114. 
Naples, N. A. (2003) 'Deconstructing and locating survivor discourse: Dynamics of narrative, empowerment, and resistance for survivors of childhood sexual abuse' Signs: Journal of Women in Culture and Society 28(4): 1151-1185.

Niemi, J. and Öhman, A. (2010) ‘Guest Editors Introduction’ Violence Against Women, Vol. 16, No. 2: 131-135.

Öhman, A. and Emmelin, M. (2014) 'Development policies, intimate partner violence, Swedish gender equality and global health' Women's studies International Forum, Vol. 46: 115122.

Perez, T. E. (2004) 'Strategies of Condescension: Latino Professors Identify Ethnic Habitual Dispositions in Their Teaching Productions' Sociological Focus, Vol.7, No. 4: 313-327.

Prop. 2005/06:155 Makt att forma samhället och sitt eget liv-nya mål $i$ jämställdhetspolitiken [Governmental Bill: Equal power to shape society and one's own life New goals for gender equality politics].

Radford, J. and Russell, D. E. H. (1992) editors, Femicide: The politics of woman killing. Buckingham, UK: Open University Press.

Scaer, R. C. (2001) The body bears the burden. Trauma, dissociation, and disease. Binghamton, NY: Haworth Medical Press. 
Scheper-Hughes, N. (1992) Death Without Weeping: The Violence of Everyday Life in Brazil, Berkeley: University of California Press.

Scheper-Hughes, N. (1996) 'Small Wars and Invisible Genocides' Social Science and Medicine, Vol. 43, No. 5: 889-900.

Scheper-Hughes, N. and Bourgois, P. (2004) editors, Violence in War and Peace: An Anthology, Malden, MA: Blackwell.

Sida (2010) On Equal Footing Policy for Gender Equality and the Rights and Role of Women in Sweden's International Development Cooperation 2010-2015, Stockholm: Government Offices of Sweden.

Smart, C. and Smart, B. (1978) 'Accounting for rape: Reality and myth in press reporting' in

Smart, C. and Smart, B. (1978) editors, Women, sexuality and social control, London: Routledge.

Stanko, E. A. (1990) 'When Precaution is Normal: A Feminist Critique of Crime Prevention' in Gelsthorpe, L. and Morris, A. (1990) editors, Feminist Perspectives in Criminology, Milton Keynes: Open University Press: 171-183.

Stanko, E. A. (2003) editor, The Meanings of Violence. London: Routledge. 
Stanko, E. A. (2006) ‘Theorizing About Violence: Observations From the Economic and Social Research Council's Violence Research programme' Violence Against Women, Vol. 12, No. 6: 543-555.

Steen, A-L. (2003) Mäns våld mot kvinnor - ett diskursivt slagfält. Reflektioner kring kunskapsläget [Men's violence against women - a discursive battlefield. Reflections on the production of knowledge], Research Report No. 131, Department of Sociology, Göteborg University.

Swahnberg, K. (2003). Prevalence of gender violence: Studies of four kinds of abuse in five Nordic countries. (Doctoral dissertation). Linköping University: Faculty of Health Sciences.

Thompson, J B. (1984) Symbolic violence: Language and power in the writings of Pierre Bourdieu. Studies in the theory of ideology, Cambridge: Polity Press: 42-72.

Topper, K. (2001) 'Not so trifling nuances: Pierre Bourdieu, Symbolic violence and the perversions of democracy' Constellations, Vol. 8, No. 1: 30-56.

Towns, A. (2002) 'Paradoxes of (In) Equality: Something is Rotten in the Gender Eqaul State of Sweden, Cooperation and Conflict: Journal of the Nordic International Studies Association, Vol. 37, No. 2: 157-179. 
Vodde, R. (2002) 'Fighting Words and Challenging Stories in Couples Work: Using Constructionist Conflict Theory to Understand Marital Conflict' Journal of Family Social Work, Vol. 6, No. 2: 69-86.

Williamson, E. and Abrahams, H. A. (2014) 'A review of the provision of intervention programmes for female victims and survivors of domestic abuse in the UK' Journal of Women and Social Work, Vol 29: 178-191. 